\title{
Sounding the 'Citizen-Patient': The Politics of Voice at the Hospice des Quinze-Vingts in Post-Revolutionary Paris
}

\author{
INGRID SYKES*
}

\begin{abstract}
This essay explores new models of the citizen-patient by attending to the post-Revolutionary blind 'voice'. Voice, in both a literal and figurative sense, was central to the way in which members of the Hospice des Quinze-Vingts, an institution for the blind and partially sighted, interacted with those in the community. Musical voices had been used by members to collect alms and to project the particular spiritual principle of their institution since its foundation in the thirteenth century. At the time of the Revolution, the Quinze-Vingts voice was understood by some political authorities as an exemplary call of humanity. Yet many others perceived it as deeply threatening. After 1800, productive dialogue between those in political control and Quinze-Vingts blind members broke down. Authorities attempted to silence the voice of members through the control of blind musicians and institutional management. The Quinze-Vingts blind continued to reassert their voices until around 1850, providing a powerful form of resistance to political control. The blind 'voice' ultimately recognised the right of the citizen-patient to dialogue with their political carers.
\end{abstract}

Keywords: Blindness; Hospice des Quinze-Vingts; Valentin Haüy; Post-Revolutionary Paris; Citizen-Patient; Sound

In 1771, a group of blind musicians performed at the Saint Ovid's Fair in Paris. A large, spectacular engraving was produced of the event entitled 'Grand Concert Extraordinaire' (see Figure 1). ${ }^{1}$ The musicians had come from the Hospice des Quinze-Vingts, an institution for the blind and partially sighted, situated on the rue Saint-Honoré. They were regular performers at the café des aveugles ('café of the blind') in the basement of the Palais Royal, and were often seen wandering the streets of Paris as individual performers or in bands. At this particular event the blind were commissioned to dress as buffoons. An accompanying verse describes the scene:

(c) Ingrid Sykes, 2011.

*Ingrid J. Sykes, Wellcome Trust Research Fellow, Centre for the History of Medicine, University of Warwick, Coventry CV4 7AL, UK. Email: Ingrid. Sykes@warwick.ac.uk

\footnotetext{
${ }^{1}$ Grand concert extraordinaire exécuté par un détachement des quinze-Vingts au Caffé des Aveugles, Foire Saint Ovide au Mois de Septembre 1771, estampe (Paris: Chez Mondhare rue St Jacques, n.d.).
} 


\section{Ingrid Sykes}

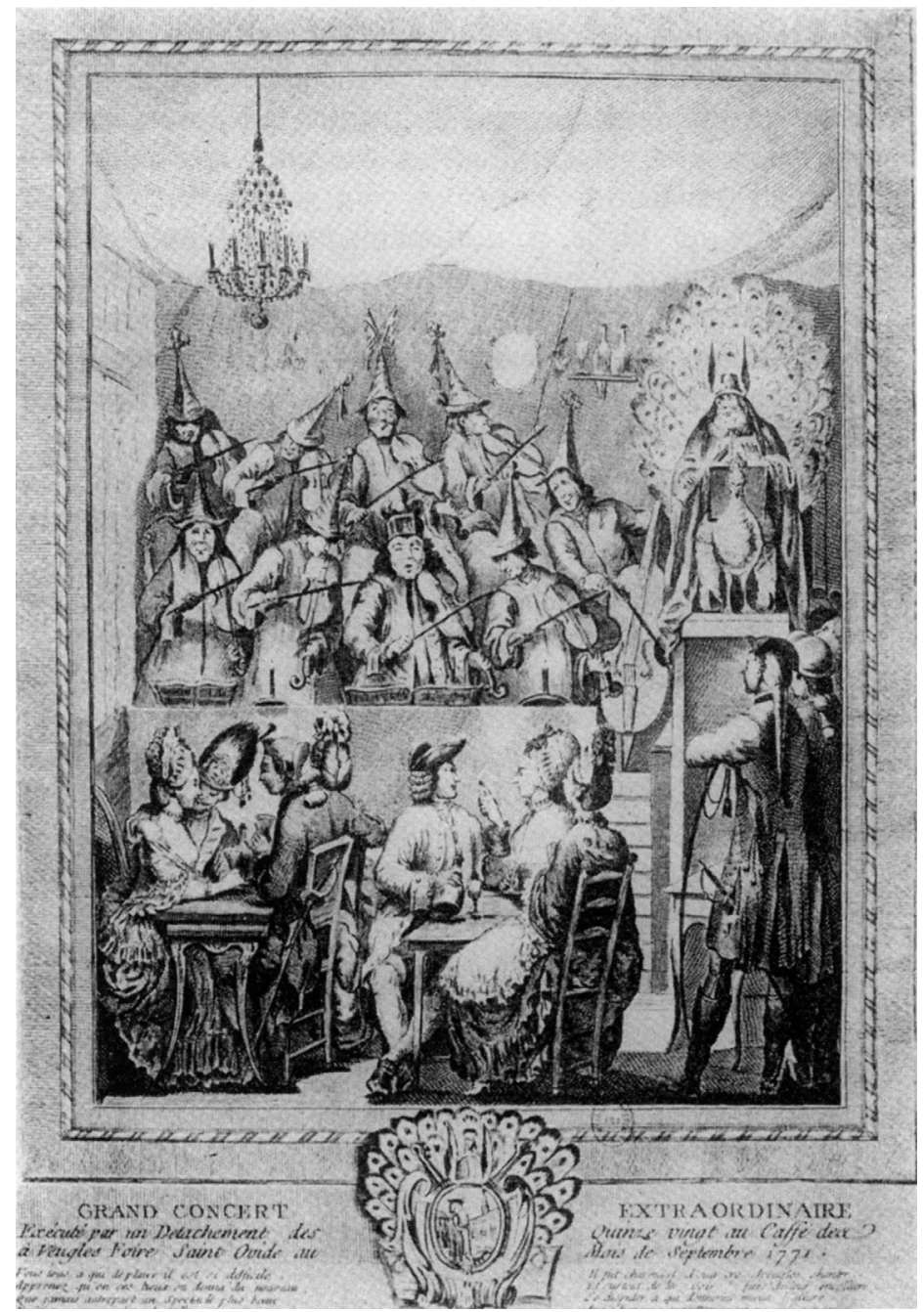

Figure 1: Grand concert extraordinaire exécuté par un détachement des quinze-Vingts au Caffé des Aveugles, Foire Saint Ovide au Mois de Septembre 1771, estampe, A Paris chez Mondhare rue St Jacques. Courtesy: Bibliothèque nationale de France (BnF).

It was lovely to hear these Blind people sing And particularly nice to see them proud Arguing as to who would give the best beat To the songs that Paris flocked to listen to. ${ }^{2}$

2 'Il fut charmant d'ouir ces Aveugles chanter/Et surtout de les voir fiers de leur encollure/Se disputer à qui donnerait mieux l'allure/Aux chansons que Paris vint en foule écouter', Almanach forain, ou Les différens spectacles des boulevards et des foires de Paris [...] (Paris: Chez Vallerye l'aîné, 1773), n.p. 


\section{Sounding the 'Citizen-Patient'}

These words describe the demeanour of the group as well as evoking the sonic and gestural nature of their performance. Zina Weygand, a leading historian of the French blind, has recently pointed out that the performance was "part of a burlesque tradition that made of the blind man a buffoon whose clumsiness provoked laughter. Deceived and deceiving blind people could still be found in the comic theatre of the day, as could the "supposedly" blind, imposters of blindness mocked by a good-natured and uninhibited public. ${ }^{3}$ Weygand has also demonstrated that the performance represented a turning point for the social integration of the French blind. In the audience was the translator and philanthropist, Valentin Haüy, who went on to establish the Institute of Blind Youth [Institut des jeunes aveugles], the eventual home of Louis Braille, five years later. Haüy was horrified at the event, writing some years later that when he saw the performance he knew the blind could do much better. He concluded that the event was a "public dishonour to the human race... "Yes", I said to myself, seized with a noble enthusiasm, "I will replace this ridiculous fable with truth. I will make the blind read; ...they will trace letters and read their own writing, I will even have them give harmonious concerts", 4

The engraving depicts an act of expressive communication through gesture and imagined sound. We see, hear and feel the literal and figurative voice of the performers. It is, to be sure, a mere representation of an event, incorporating elements of caricature and prejudice into its interpretative quality. Yet the sheer dynamism of the blind musicians' bodily performance suggests the motivation of the group to communicate. This aspect of the event is highlighted through a number of different visual means. Aside from their position on an elevated stage, the musicians' bodies move about in the broadest spatial range. Bodies usurp blind faces. Torsos lean over and elbows jut out so much that instruments and bodies collide. The movement is such that the performers' clown hats almost fall off. Musical instruments are part of the dynamic energy of the group. Bows move at a variety of different angles and speeds. Instruments themselves are positioned more or less randomly, as comfort or habit permit. Some musicians appear to be listening to each other, their bodies and heads leaning inwards towards the centre, some not. Some face forward. One violinist and his instrument are turned towards offstage. Another, ear and head downwards, listens to his violin. This is a spectacle of extreme human movement. Music is at the source of the action. But was this even music? Musical scores are redundant props. Sounds come directly from bodies themselves. Reports of the music describe only that: 'Each person took a turn to sing verses of humorous little songs while playing the violin in a funny way and they all joined in for the chorus. ${ }^{5}$ There

\footnotetext{
${ }^{3}$ Zina Weygand, The Blind in French Society: From the Middle Ages to the Century of Louis Braille, Emily-Jane Cohen (trans.) with a preface by Alain Corbin (Stanford: Stanford University Press, 2009), 91; the original French version of the book is Zina Weygand, Vivre sans voir: Les aveugles dans la société française, du Moyen Age au siècle de Louis Braille, préface d'Alain Corbin (Paris: Créaphis, 2003).

${ }^{4}$ Ibid., 91-2. Weygand quotes Valentin Haüy, Troisième note du citoyen Haüy, auteur de la
}

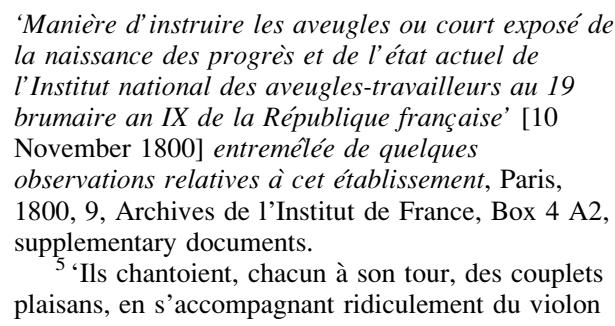

'Manière d'instruire les aveugles ou court exposé de la naissance des progrès et de l'état actuel de l'Institut national des aveugles-travailleurs au 19 brumaire an IX de la République française' [10 November 1800] entremêlée de quelques observations relatives à cet établissement, Paris, 1800, 9, Archives de 1'Institut de France, Box 4 A2, supplementary documents.

5 'Ils chantoient, chacun à son tour, des couplets plaisans, en s'accompagnant ridiculement du violon 


\section{Ingrid Sykes}

were just snippets of melody, sometimes supported by a few chords, sometimes not. It is difficult to imagine the exact sonic landscape. But this was clearly extraordinary music surpassing every boundary imaginable amongst musical performers of any kind.

Voice, in this context, was not simply the articulation of speech. Rather, it was a more complex display of influence or power amongst individuals or collective groups. The expression of voice could incorporate elements of gesture and sound into its statements. ${ }^{6}$ During the late eighteenth century, ideologues such as Valentin Haüy were attempting to refine the presentation of voice. Gestural, sonic and visual signs were developed into semantic systems, for that would not only replace the 'single' voice or will of the King, but represent Enlightenment ideals of truth and reason most fully. ${ }^{7}$ These systems were carefully defined by the philosophes in their writings and practised in new educational institutions and other sites related to the emerging public sphere. From this perspective, the musicians represented in the engraving displayed a defiant voice. ${ }^{8}$ Their practice does not appear to conform to any standard lingual code or pre-ordained formal structure acceptable to the eyes and ears of contemporary educated bourgeois writers. The performance might be interpreted as an extreme expression of will. Might Haüy have found the voice of the performance too unsophisticated?

There may be a broader set of issues behind Haüy's response relating to the emerging culture of public health and medical assessment during the late eighteenth-century

et ils répétoient en chœur le refrein des couplets', Almanach forain, op. cit. (note 2).

${ }^{6}$ This study parallels recent scholarship on the history of sound. See, for example, Mark Smith (ed.), Hearing History: A Reader (Athens, GA: University of Georgia Press, 2004); Jonathan Sterne, The Audible Past: Cultural Origins of Sound Production (Durham, NC: Duke University Press, 2003); Emily Thompson, The Soundscape of Modernity: Architectural Acoustics and the Culture of Listening in America 1900-1933 (Cambridge, MA: MIT Press, 2002); Karin Bijsterveld, Mechanical Sound: Technology, Culture and the Public Problems of Noise in the Twentieth Century (Cambridge, MA: MIT Press, 2008); Pierre Bourdieu, Distinction: A Social Critique of Judgement of Taste, Richard Nice (trans.) (Cambridge, MA: Harvard University Press, 1984). On sound in nineteenth-century France, see Alain Corbin, Village Bells: Sound and Meaning in the French Countryside, Martin Thom (trans.), (London: Papermac, 1999). The idea of 'voice' history is a more complex extension of sound history, focusing not simply on material sounds of the past but also the cultural, political and social expressions of collective groups of people as well as the objects and structures they possess and inhabit. Voice history draws on elements of sound description such as grain and timbre to explore various modes of expression.

${ }^{7}$ Sophia Rosenfeld, A Revolution in Language: The Problem of Signs in Late Eighteenth-Century France (Stanford: Stanford University Press, 2007). Further literature on the history of sign includes
Claudia Stein, Negotiating the French Pox in Early Modern Germany, History of Medicine in Context (Aldershot: Ashgate, 2009), K. Codell Carter, The Rise of Causal Concepts of Disease: Case Histories (Aldershot: Ashgate, 2003); Nancy Siraisi, 'Disease and Symptoms as Problematic Concepts in Renaissance Medicine', in Eckhard Kessler and Ian Maclean (eds), Res et verba in der Renaissance (Wiesbaden: Harrassowitz, 2002), 217-39; Ian Maclean, Logic, Signs and Nature in the Renaissance: The Case of Learned Medicine (Cambridge: Cambridge University Press, 2001); Ian Maclean, Le monde et les hommes: Selon les médecins de la renaissance (Paris: CNRS, 2006); and Andrew Cunningham, 'Identifying Diseases in the Past: Cutting through the Gordian Knot', Asclepio 54, 1 (2002), 13-34.

${ }^{8}$ The most important study examining the broader cultural implications of music for this period is James H. Johnson, Listening in Paris: A Cultural History (Berkeley: University of California Press, 1995). See also Downing A. Thomas, Aesthetics of Opera in the Ancien Régime 1647-1785 (Cambridge: Cambridge University Press, 2002). For a study of more popular forms of musical expression, see Joseph Ploch, 'Chanteurs Chansonniers sous l'Ancien Régime', in Florence Gétreau and Michel Colardelle (eds), Musiciens des rues de Paris (Paris: Réunion des musées nationaux, 1997), 34-40; and Laura Mason, Singing the French Revolution: Popular Culture and Politics, 1787-99 (Ithaca, NY: Cornell University Press, 1996). 


\section{Sounding the 'Citizen-Patient'}

period. These relate to the establishment of culturally defined ideas of 'good' and 'bad' voices. Medical bodies during this period were increasingly deemed healthy and unhealthy on the basis of signs and symptoms. ${ }^{9}$ A certain gesture, sound or sign emanating from the body determined its place within this rigid classification system. By extension, individuals and collective groups of people could also be considered healthy or unhealthy depending on their mode or tone of voice, the signs or symptoms they displayed through their expressive behaviour. Valentin Haüy assessed the Quinze-Vingts voice as essentially an unhealthy one, in need of reform. He, along with state authorities during the post-Revolutionary period, would embark on a programme of medical cure and rehabilitation of the Quinze-Vingts voice.

Zina Weygand has presented the history of the French blind through a narrative of remarkable social transformation. ${ }^{10}$ She argues persuasively that the establishment and reform of blind institutions led to increasing social understanding towards the group. Weygand emphasises the development of written language for the blind in the $1820 \mathrm{~s}$ and 1830s by Louis Braille and others at the Institute for Blind Youth in Paris, explaining that 'it would at once be a means of embracing universal culture and a federative element for the emerging community of blind, educated people'. ${ }^{11}$ This emancipation was the result of a slow process of change, however. As Weygand explains, the group had long held a special position in French society and institutions for the blind and partially sighted had existed since the thirteenth century. Early institutions, notably the Hospice des Quinze-Vingts, founded by Louis IX, had at their core the object of charitable assistance. ${ }^{12}$ The '300' (hence Quinze-Vingts: $15 \times 20$ ) blind and partially sighted members were granted the privilege of creating their own congregation and receiving alms from the community. When they went out on the street to beg they wore a special 'uniform' embroidered with a royal fleur-de-lis. There were both blind men, many with sighted spouses, (named frères and sæurs until the Revolution), and blind single women, as well as sighted members generally entrusted with their care. Though they were a secular order they gave all their goods to the institution. The blind played a central role in managing the site. According to Weygand, all members attended weekly chapter assemblies and there was a small group of six blind managers - named Jurors [Jurés] - headed by a sighted master who took decisions on the running of the community. The QuinzeVingts community articulated a collective voice based on its own spiritual power and influence during the early modern period.

Weygand describes in detail the tumultuous history of Quinze-Vingts after the Revolution. It survived relatively intact but its charitable status brought the stigma of 'idleness'. As Weygand explains, 'the brothers and sisters of the Quinze-Vingts hospice, now joined by blind provincials pensioned by the establishment, helped perpetuate the image of the blind man "of no use to himself or to society", incapable of being integrated into the world of communication through education or into channels of socio-economic

\footnotetext{
${ }^{9}$ See Foucault's discussion of Condillac's interest in signs in The Birth of the Clinic: An Archaeology of Medical Perception, A.M. Sheridan (trans.), repr. (London: Routledge, 2007), 142-3.

${ }^{10}$ Weygand [English version], op. cit. (note 3).

${ }^{11}$ Weygand, ibid., 299.
}

\footnotetext{
${ }^{12}$ Other studies examining the 'long' history of Quinze-Vingts include, Louis Guillaumat et JeanPierre Bailliart, Les Quinze-Vingts de Paris: échos historiques du XIIIe au XXe siècle, with Geneviève Charles and Paul Bonnin (Paris: Société Francophone d'Histoire de l'Opthalmologie, 1998).
} 


\section{Ingrid Sykes}

exchange through work. ${ }^{13}$ In 1801, Quinze-Vingts was amalgamated briefly with the more famous Institute for Blind Youth established by Valentin Haüy in 1784. The Institute was heavily influenced by the writings of Diderot, who had observed that blind people could 'learn to see' through touch and sound. It was launched through a series of public events, the largest at Versailles in 1786, which demonstrated the ability of the young blind to learn a respectable trade and practise the sciences and the arts. Haüy resigned after a political dispute with the Minister of the Interior [Ministre de l'Intérieur], Jean-Antoine Chaptal, in 1802. The Institute then left the Quinze-Vingts site for the rue Saint-Victor in 1816 when it was placed under the directorship of Sébastian Guillié, then Alexandre-René Pignier. Weygand describes the blind writing systems which were then introduced to the institution. The 'night-writing' system by Charles Barbier de La Serre - a writing method using 'combinations of simple signs representing letters and sounds ${ }^{14}$ - was first used with blind pupils in 1821 , followed by Braille (the dot-raised system), taught by the inventor himself in 1830 . Whilst the Institute for Blind Youth blossomed, Quinze-Vingts remained in shadow, however. Weygand explains that it became a particular target of government social control. It was eventually fully secularised.

This article attempts to build on the work of Weygand and others by examining Quinze-Vingts from the perspective of the blind voice. The phrase 'la voix' appears time and time again in Quinze-Vingts documents after the Revolution. The blind requested the right to their own 'voice' frequently when writing to authorities. At first glance, the meaning of the blind voice is confusing. What is the blind voice in this context? A closer reading reveals that the notion of 'voice' held a very personal sense for the blind in the post-Revolutionary space. 'Voice' had been an intrinsic cultural feature of the Quinze-Vingts institution in both a literal and figurative sense since its foundation. Musical voices at Quinze-Vingts had been used in mediaeval times to express the particular spiritual power of blind members. The institution also voiced its own spirit of collective independence within the social and political landscape. After the Revolution, this act of vocalisation took on a more defiant tone when the institution was under threat. The post-Revolutionary blind voice redefined the Quinze-Vingts community as a collective group in relation to the very different political circumstances surrounding them. It could revive a sense of the embodied institutional space when Quinze-Vingts was attacked by those in political control. There is much more, however, to be learned from the blind's recourse to voice during this period. Indeed, there was a complex series of vocal demonstrations made towards the blind by those in political authority. Post-Revolutionary governments dealt with Quinze-Vingts by manipulating their own voices. They too were highly attuned to the power of voice. Members of the Convention praised those who might 'listen' to the blind voice, for example. It was not enough to simply 'hear' their voices, they explained. Those in power should comprehend and feel empathy with their particular affective qualities. The desire for some form of dialogue with the institution by those in political power was short-lived, however. The blind voice was immediately interpreted as a threat. From 1800, political authorities used their own voices to silence it or reform it with the aim of medical cure.

\footnotetext{
${ }^{13}$ Weygand, op. cit. (note 3), $117 . \quad{ }^{14}$ Ibid., 276.
} 


\section{Sounding the 'Citizen-Patient'}

Sophia Rosenfeld has demonstrated that at the time of the Revolution the notion of voice was a contentious issue amongst all peoples. ${ }^{15}$ To raise one's voice was to seize a highly politicised form of power. The Quinze-Vingts community were not the only group to capitalise on the idea of voice in an effort to gain attention. Yet they cut against the pervading trend amongst many revolutionaries and recipients of revolutionary values to construct a moral code of signs. Rather, they positioned their often abrasive 'voice' across a number of different spatial and bureaucratic contexts. Off-key musical voices were synonymous with the voices of complaint referred to in administrative documents. Begging voices were also the spiritual voices of the worshipping blind. Their ability to present a unified voice across time and space in the post-Revolutionary period has much to do with the powerful culture of the institution at its establishment. Here, loud musical voices emanating from the institution inscribed the same spiritual meaning as administrative blind voices articulating their importance within mediaeval society. After the Revolution, this voice took on a highly political tone that drew attention to the needs of citizen-patients in the rapidly-changing urban environment.

The terms 'citizen-doctor' and 'citizen-patient' were originally coined by the medical historian Dora Weiner to emphasise the new civil spirit of post-Revolutionary medical identities. ${ }^{16}$ She has demonstrated that physicians and patients during this period were involved in a sophisticated dialogue of care. Reform of administrative systems, institutions and new methods of medical practice attended to the needs of citizen-patients in new and inventive ways. Weiner's construction of the citizen-patient is, however, a relatively passive figure in her narrative of medical progress. The blind, in particular, are relegated to mere recipients of state educational control and urban redevelopment. I wish to add to Weiner's vision of the citizen-patient by suggesting that the figure in some contexts actively demanded a particular humanitarian culture of patient care. The voice of the citizen-patient initially chimed with that of the democratic citizen-self who had immense sympathy for the afflicted, but it was immediately perceived by authorities as violent. Such shifting tones of voice reveal the nuances in the history of the development of the citizen-patient. The politics of voice and vocal interaction was central to its unfolding social, political and cultural construction.

\section{Hearing and Understanding the Blind Voice}

Louis IX had a particular goal in mind when he founded the Hospice des Quinze-Vingts in the mid-thirteenth century. Mark O'Tool has drawn attention to the close relationship between the King's own experience of chronic illness and his perception of the blind. ${ }^{17}$ He maintained a 'firm belief that those who suffered from any affliction - including blindness - were worthy of charity if they endured their afflictions with patient devotion and humility like he had'. ${ }^{18}$ The Quinze-Vingts 'voice' became synonymous with the sound of the blind-afflicted self. Those who gave money to musicians there, and to those

\footnotetext{
${ }^{15}$ Rosenfeld, op. cit. (note 7), 127.

${ }^{16}$ Dora B. Weiner, The Citizen-Patient in Revolutionary and Imperial Paris (Baltimore: John Hopkins University Press, 1993).
}

\footnotetext{
${ }^{17}$ Mark Polking O'Tool, 'Caring for the Blind in Medieval Paris: Life at the Quinze-Vingts, 1250-1430' (unpublished PhD thesis: University of California, 2007).

${ }^{18}$ Ibid., 107.
} 


\section{Ingrid Sykes}

Quinze-Vingts beggars on the street, recognised that they were activating its spirit through sound. Blind members and their sighted carers literally gave their voices to the Quinze-Vingts community when they entered. The individual 'voice' engaged in prayer, music and street-begging on behalf of the collective institution. Quinze-Vingts members were the focus of a significant number of bequests from the upper echelons of the bourgeois community of Paris for the foundation of memorial masses. ${ }^{19}$ When the memorial mass was sung in the Hospice chapel, the musicians from the community transported the soul of the benefactor to salvation through the sound of their blindafflicted selves. The affective vocal quality of the blind musician's performance was directly replicated in the behaviour of the institutional space. This was primarily ritualistic, involving a specific initiation process, communal attendance at mass, bell ringing, and a particular moral code. Quinze-Vingts remained distinct from other religious houses through its particular sense of autonomy. Quinze-Vingts fought off other blind houses (Six-Vingts, for example, a house for ' 120 ' blind people founded in 1292 by Renaut Barbou the Elder) for the most powerful right to sound the blind voice. ${ }^{20}$ Quinze-Vingts members saw themselves as retaining the uppermost privilege amongst other blind institutions to harness their own 'voice' on their own terms. Mark O'Tool has explained: 'Rather than marginalize the blind residents, this community was designed to care for them and even showcase their religiosity. ${ }^{21}$ This was reflected in the unique administrative structure of the institution allowing the blind, supported by the sighted, an important say in the running of the site.

During the late seventeenth and early eighteenth centuries, the potent voicing of the collective Quinze-Vingts community remained an important feature of the urban landscape. ${ }^{22}$ The presence of Quinze-Vingts on the street still remained explicitly connected to the spirituality of blindness. In 1744, for example, a group of Quinze-Vingts celebrated the King's return from the German war front.

Lord restore our sight that we may see the King,

For just one moment,

So that we no longer complain to you,

That we have lost it:

\footnotetext{
${ }^{19}$ For full details on the use of memorial masses at Quinze-Vingts, see ibid., 260-303.

${ }^{20}$ Ibid., 242-53.

${ }^{21}$ Ibid., 176.

${ }^{22}$ During this period, Quinze-Vingts held a collection of diverse musical instruments as well as special furniture in which to store them. There were large chests and cupboards containing pipes, violins, a viola, cellos, basses, an oboe, five clarinets, a number of horns and their crooks, five bassoons, a trombone, three serpents (large wind instruments made of brass, wood and leather), a trumpet, three sets of cymbals, a guitar, a keyboard, three violin rests and one bass rest. Music for official ritual, both military and liturgical might easily have formed the repertoire for this collection, and contemporary and ancient music for
}

mass formed the bulk of the printed library collection. The colourful nature of the instrument collection made it suitable for many other forms of musical expression, however. Although such repertoire would never have been notated, and hence no sheet music survives, the instrumentation suggests that QuinzeVingts musicians performed popular chanson in a multitude of different improvised formats both collectively (in a band) and individually (as a solo). See 'État des meubles, instrumens et musique appartenans à l'hospice des 15-20 existant dans la salle d'instruction dudit hospice', B 113/6795 and 'Musique', B 113/6795, Archives du Centre Hospitalier National d'Opthalmologie des QuinzeVingts [hereafter AQV] Bibliothèque. 


\section{Sounding the 'Citizen-Patient'}

You will not be able to find, Lord,

Our requests strange;

When those least able to hear have the pleasure

Of hearing the praises. $^{23}$

Encoded within the song are all the characteristics of the spiritualised Quinze-Vingts 'self'. Blindness is viewed as a way of praising the divine kingdom. These praises are deliberately bold because they need to be heard by all (even 'those least able to hear'). Quinze-Vingts blindness was still expressed in the form of a spiritualised speech-act. Yet, Quinze-Vingts musicians had also become closely associated with the more secular world of the burlesque. Quinze-Vingts musicians could be seen and heard on the Pont Neuf, at the café des aveugles and, as we have seen, at Saint Ovid's Fair. ${ }^{24}$ These appearances were influenced by the mediaeval tradition of the French blind farce. ${ }^{25}$ In this genre the singing blind beggar (played by a sighted man) was belittled through the appearance of a sighted guide who reveals the blind man to be morally unworthy of help. It is possible, however, to interpret the performance at the Saint Ovid's Fair as somewhat more nuanced in meaning. By masquerading as singing blind beggars (dressed up and led by their instruments), the Quinze-Vingts blind were recalling the genre whilst also maintaining their traditional style of performance. From the audiences' point of view, the instrumental group resembles the farcical combination of passive blind beggars (the blind playing the sighted playing the blind) led by a sighted guide (the musical instrument). The musical instrument is the ideal bodily accompaniment because, as in the original farce, it 'speaks' for the blind man. From the blind's perspective, however, the costumes and the instruments are used to 'act up' their traditional role as blindafflicted selves. The instruments, in particular, are employed as 'double bodies', enhancing the traditional Quinze-Vingts quality of bodily affliction by morphing with the blind body. $^{26}$ Thus, the grotesque body of the carnivalesque was, from the blind person's point of view, not necessarily contradictory to the suffering blind bodily figure emblematic of the Quinze-Vingts institution. Spiritual transformation, albeit in a new more 'hedonistic' form, still resided deep within Quinze-Vingts bodies that continued to reinvigorate themselves on the burlesque stage.

The 'double body' form was out of place in the new Enlightenment world of idealistic lingual purity. It is possible that Haüy saw, not only the belittling of the blind, but a dislocated sound and sight in the performance at Saint Ovid. Here, the blind voice appeared to speak through the instrumental body, or the 'costumed body', not from the blind mouth itself. The dislocated voice was intrinsic to the traditional Quinze-Vingts mode of performance. The voice of the Quinze-Vingts musician had a particular potency which

\footnotetext{
23 'Grand Dieu rends-nous pour voir le Roi,/Un seul instant la vûe,/Pour ne nous plaindrons plus á toi,/Que nous l'avons perdue:/Tu ne saurois trouver Seigneur,/Nos Requêtes etranges;/Quand les plus sourds ont le bonheur/D'entendre les louanges', 'VII, Chanson, Oraison des Quinze-Vingts sur l'Air De Joconde', in Chansons sur le retour du Roy, et sur son heureuse arrivé[?] à Paris (Paris, 1744), 14.

24 'Et les plus argus sont de vrais Quinze-Vingts. Théâtre It. Arleq. Phœnix', in Philibert-Joseph Le
}

Roux, 'Quinze-Vingts', Dictionnaire comique, satyrique, critique, burlesque, libre et proverbial... (Amsterdam: Chastelain, 1750), 220.

${ }^{25}$ O'Tool, op. cit. (note 17), 61-72; see also Weygand, op. cit. (note 3), 14-17.

${ }^{26}$ For a discussion of eighteenth-century uses of the 'double-body' see Terry Castle, Masquerade and Civilisation: The Carnivalesque in Eighteenth-

Century English Culture and Fiction (Palo Alto, CA: Stanford University Press, 1986). 


\section{Ingrid Sykes}

sometimes transcended the presence of the physical body to which it belonged. Haüy was not alone in his fear of the 'raucous' voice. During the later part of the eighteenth century, it was identified as a serious problem in the urban environment. In his 1783 essay, Tableau de Paris, Louis-Sébastien Mercier expressed concern at some of the sounds and sights of Parisian street life. ${ }^{27} \mathrm{He}$ explained that he was deeply embarrassed by the number of beggars in the city who spilled out onto the street during the day from their various institutional houses. He made a specific attack on the 'mendiants valides' ['able-bodied beggars'] who he saw as exploitative of everyday people. ${ }^{28}$ This was obvious in their physical demeanour which he described as ghastly and frightening. 'They follow you in the streets slowly uttering the sacred name of God in an unnatural, sorrowful, and monotonous voice. ${ }^{29}$ Mercier saw such beggars as duplicitous. They received charity at home but lie on the street. Worse still, they shirked work on the basis that they are physically suffering. But, he warned, this was all an act of corruption. If you followed the beggars into the cabarets at night you would see and hear their violent behaviour. They were not suffering at all.

The lame person has discarded his crutch, the blind man his patch, the hunchback his horsehair hump, the one-armed person takes the violin, the dumb signal a frenetic lack of restraint... They boast about taxes removed from public sensitivity, violence that they inflict on compassionate and gullible souls. They pass on their secrets to each other; they repeat their pitiful roles with disrespectful outbursts of laughter. ${ }^{30}$

Mercier's negative characterisation of the mendiants valides is through a figure of vocal and bodily separation. The whining voice of the beggar appears to come from a source outside the beggar's human self. ${ }^{31}$ The bodies of the figures move about like dismembered limbs. The beggars resemble mechanistic puppets, figures of the Freudian uncanny. ${ }^{32}$ There is something frightening and deathly entering the beggar's human selves. The unknowable in this description is most powerfully depicted in the beggar's voices. Not only does the 'voice' sound horrible but it takes on a violent life of its own through secret communication and revolting laughter. It is possible that QuinzeVingts musicians were amongst those depicted in this performance. According to the new Enlightenment interest in pure sign, their 'voices' are no longer recognised as spiritually meaningful, but overbearing and threatening. To a certain extent, Mercier

\footnotetext{
${ }^{27}$ See, for example, Louis-Sébastien Mercier, Le tableau de Paris, Jeffrey Kaplow (ed. and intr.), (Paris: La Découverte, 1998).

${ }^{28}$ Ibid., 151-2. The simple mendiants [poor beggars] were victims of state legislation which confined them to the 'cruelty' of the poor houses, the depots, ibid., 148-9,

29 'D'une voix artificielle, plaintive et monotone, ils articulent en traînant le nom de Dieu, et vous poursuivent dans les rues avec ce nom sacré, ibid., 151.

30 'Le boiteux a jeté sa béquille, l'aveugles son emplâtre, le bossu sa bosse de crin; le manchot prend un violon, le muet donne le signal de l'intempérance effrénée... Ils se vantent des impôts prélevés sur la
}

sensibilité publique, de la violence qu'ils font aux âmes compatissantes et crédules. Ils se communiquent leurs secrets; ils répètent leur rôles lamentables avec des éclats de rire licencieux', ibid.

${ }^{31}$ For the unsettling nature of spectacles involving vocal dislocation see Steven Connor, 'Violence, Ventriloquism and the Vocalic Body', in Patrick Campbell and Adrian Kerr (eds), Performance and Psychoanalysis (London: Routledge, 2001), 75-93.

${ }^{32}$ See Sigmund Freud, 'Uncanny', in James Strachey (ed.), An Infantile Neurosis and Other Works, (1917-1919) in The Standard Edition of the Complete Psychological Works of Sigmund Freud, Vol. 17 (London: Hogarth, 1955), 217-52. 


\section{Sounding the 'Citizen-Patient'}

attempted to silence this kind of voice through his own condemnation in the text. He confronted the violent voice with a threatening voice of his own. His voice carries with it the sophistication and cultivation of a knowledgeable writer. This enables him to raise the public alarm.

Mercier's reading reflects the anti-clericalism of the immediate post-Revolution. ${ }^{33}$ The violence of these characters is caused by God. What is heard in their chattering speech is the hideous voice of an unseen God who corrupts the human form. It is the violent voice, however, that is the pivotal subject of Mercier's description. It allows him to heighten the emotional level of the text and to create a sense of the threatening (the beggars) and the threatened (himself and the public). In Haüy's eyes and ears, the QuinzeVingts musicians at Saint Ovid's fair might also have posed a threat. They presented a literal voice that was shrill and confronting, but also a figurative voice that was inherently problematic from a bourgeois political and social point of view. Haüy's response was to desire another voice in the form of 'harmonious concerts' that might drown these musicians out. Such a voice would be beautiful and seductive to members of the public. The cultivated listener would engage with it through a profound emotional comprehension. Haüy believed he could help all the blind in this aim and he demonstrated with his work at the Institute for Blind Youth that his programmes could be a success. These were closely constructed according to his philanthropic belief in human happiness and the power of the sciences and the arts to transform people's lives. The blind poor could learn a respectable trade through appropriate training. Yet, like Mercier, he was also expressing a certain anxiety about public health common amongst the post-Revolutionary bourgeoisie: this was that the voice of the blind must be silenced or soothed. It is probable that Haüy heard the ugly, confused tones of popular speech, the visceral cry of birth and death in the music. This was 'bad' music producing sounds far too closely related to the uncivilised cycles of bodily transformation. In his educational manifesto he was later to write: 'It is probably a lack of principles that reduce some to rushing around the streets going from door to door shattering ears with an out-of-tune instrument or a raucous voice, trying to obtain small change often given to them in return for quiet. ${ }^{34}$ Haüy's interpretation of the Quinze-Vingts voice was that it represented a corrupted body. This, in his opinion, should be 'cured' through the implementation of training programmes within the institution and carefully controlled public presentation.

Bourgeois anxiety over public health was centred on the perceived poor population. Catherine Kudlick has traced its period of development from the middle of the eighteenth century to the cholera outbreaks of the mid-nineteenth century. ${ }^{35}$ Kudlick explains that ideas relating to public health were initially furnished in the Enlightenment in an attempt

\footnotetext{
${ }^{33}$ It should be noted that the Church also took a similar stance against such street beggars during this period. On the Church and the Revolution see Nigel Aston, Religion and Revolution in France, 1789-1804 (Basingstoke: Macmillan, 2000).

34 'Ce n'est que faute de principles sans doute, que quelques'uns sont réduits à courir les rues, pour aller de porte en porte déchirer les oreilles, à l'aide d'un instrument discord ou d'une voix rauque, afin d'arracher une légère pièce de monnoie qu'on leur donne souvent en les priant de se taire', Valentin
}

Haüy, Essai sur l'éducation des aveugles (Paris: Imprimé des Enfants-Aveugles, 1786), 85-6.

${ }^{35}$ Catherine J. Kudlick, Cholera in PostRevolutionary Paris: A Cultural History (Berkeley, CA: University of California Press, 1996). For another key text on health and the working classes during this period, see Louis Chevalier, Classes laborieuses et classes dangereuses à Paris pendant la première moitié du XIXe siècle (Paris: Pion, 1958). For more recent texts on France and public health see Ann La Berge, Mission and Method: The Early 


\section{Ingrid Sykes}

to improve poor people's lives. ${ }^{36}$ The Revolution brought with it the turbulence that would require these ideas to be put into practice. It also brought an increasing division between the rich (the givers of health) and the poor (the recipients of health). Disease in the urban environment had been attributed to the behaviour and existence of the poor since the seventeenth century. As Foucault has famously demonstrated, confinement was considered an effective means for the suppression of both poverty and disease. ${ }^{37}$ By the time of the Revolution, Quinze-Vingts was administered entirely separately from the official houses for the poor, the hôpitaux généraux. Nevertheless, it was considered similarly poor and diseased by the authorities on the basis of its perceived antisocial behaviour. ${ }^{38}$ The Enlightenment culture of signs was now embedded in the language of the law. ${ }^{39}$ Those unable to conform to an acceptable code of behaviour were considered close to savages and treated as 'ill'. Much of this political viewpoint was initially expressed in concern over the religious nature of its character. At stake was the issue of bodily corruption. Just prior to the Revolution the then Superior General, the Grand Almoner Cardinal de Rohan, had been accused by the parlements of serious financial corruption during the Hospice's move to the Rue de Charenton. An enquiry had been ordered. ${ }^{40}$ Further problems, however, emerged later in the behaviour of the blind internal administrators, the Jurors. Jurors were accused of forcing members, still named 'frères', to swear allegiance to the institution in the manner of a religious brotherhood. The question constantly posed by authorities was: 'Is there good order and decency within the Hospital? ${ }^{41}$ Such a question undermined the independent voice of the Jurors.

On 5 November 1790 the institution was officially placed under the protection of the National Assembly [Assemblée Nationale] and the Jurors continued meeting unofficially. Petition aside, Quinze-Vingts, now situated in one of the poorest quartiers of Paris, was viewed by the State as an important participant in the new post-Revolutionary culture of bienfaisance. ${ }^{42}$ Like many of the parish-based institutions for poor-relief, Quinze-Vingts was transferred to the Paris Commune's Municipal Commission [Commission Municipale] in 1791, which employed state commissioners to liaise with local clerical administrators to instil civic pride. This move sparked protest amongst Quinze-Vingts members,

\footnotetext{
Nineteenth-Century Public Health Movement (Cambridge: Cambridge University Press, 1992), and David Barnes, The Great Stink of Paris and the Nineteenth-Century Struggle Against Filth and Germs (Baltimore, MD: John Hopkins University Press, 2006). For a more general social history of the extended post-revolutionary period see Peter McPhee, A Social History of France, 1789-1914, 2nd edn (Basingstoke: Palgrave Macmillan, 2004).

${ }^{36}$ Robert Roswell Palmer, The Improvement of Humanity: Education and the French Revolution (Princeton, NJ: Princeton University Press, 1985); and Rosenfeld, op. cit. (note 7).

${ }^{37}$ Michel Foucault, Madness and Civilisation: A History of Insanity in the Age of Reason, Richard Howard (trans.), repr. (London: Routledge, 1997).

${ }^{38}$ Weygand discusses the low socioeconomic status of Quinze-Vingts members at the beginning of
}

the nineteenth century. See Weygand, op. cit. (note 3), 182-6; Mark Polking O'Tool demonstrates that at the institution's foundation, many members came from the working poor and lower middling areas of the bourgeoisie, see O'Tool, op. cit. (note 17), 118-71.

${ }^{39}$ Rosenfeld, op. cit. (note 7), 236.

${ }^{40}$ See the document, Affaire des Quinze-Vingts

(Paris, 1789), Collection, Les archives de la

Révolution française.

${ }^{41}$ 'Le bon ordre et la décence regnent-ils dans l'intérieur de 1'Hôpital?', Pièces justicatives, 5, ibid.

${ }^{42}$ For the culture of bienfaisance after the Revolution, see Isser Woloch, 'From Charity to Welfare in Revolutionary Paris', The Journal of Modern History, 58, 4 (1986), 790-812. 


\section{Sounding the 'Citizen-Patient'}

who resented the gaze of any specific administrator, religious or secular, appointed without their permission. ${ }^{43}$ During this time, the Paris Department had also received a complaint from a blind couple, M. Gauthier and Mme Lidelle, who had been excluded from the institution by the members themselves during the turbulent period of institutional relocation. ${ }^{44}$ The Jurors had expelled at least four members for marrying without their authorisation. This move went unreported during the affair, but the newly established Committee of Public Assistance [Comité des Secours Publics] was subsequently informed of the expulsions. In 1793, the Committee recommended suppression of the institution. ${ }^{45}$ Of most concern was the perceived inappropriate behaviour of the Jurors. It was the Jurors who had created the need for the original enquiry, the Committee complained, by expelling members who had rights to accommodation within the institution's grounds. They were also in agreement with complaints made by the commune clerk that the institution was deeply undemocratic, privileging only a few blind people from Paris. ${ }^{46}$

The report by the Committee of Public Assistance included a scathing attack on the institution's 'behaviour'. This was couched in distinctly bodily terms. The institution was a collective body of sick individuals:

So many people of any age or sex, most destined to live in idleness, can only be mutually depraved thus piled up (if I may use this expression) in cramped and enclosed conditions. Also, for some years now, there have been serious complaints concerning the licentious life led in this house. The disturbances had inevitably grown in recent times as a result of the spirit of independence, division and anarchy which was adopted there. ${ }^{47}$

Such a statement recalled the bodily sounds and images of the mendiants valides as described by Mercier. The Quinze-Vingts 'body' moved about without the anchor of any moral code. The site is described as having no rational moral compass to guide its behaviour. Though the individual blind self remained connected to its collective Quinze-Vingts home, it now belonged to a diseased group of citizens who created an extreme level of aggressive noise through unregulated behaviour. By recognising the violent voice in the dynamics of the Quinze-Vingts space, the Committee of Public Assistance also implied the need for the firm voice of authority. This, they believed, would be expressed in the drastic act of suppression.

Yet suppression was avoided. There was one authoritarian voice amongst the postRevolutionary who cherished the voice of the Quinze-Vingts blind. A document refuted

\footnotetext{
43 'Pétition presentée á l'Assemblée Nationale par les frères aveugles et voyants de l'hôpital des QuinzeVingts', le 19 9bre, 1792. All manuscript petitions from this point on are from B 107-6678, B 1096724 , B 115 6829, AQV.

${ }^{44}$ Département de Paris, 'Extrait des registres des délibérations du Directoire', manuscript, 10 mai, an 2.

${ }^{45}$ F.G. Riffard and S. Martin, Convention nationale: Rapport sur l'Hôpital des Quinze-Vingts (Paris, 179-), Collection, Archives de la Révolution française.
}

\footnotetext{
${ }^{46}$ Commune de Paris, 'Extrait du registre des deliberations du Conseil-Général', manuscript, 15 frimaire an 2 .

47 '[T]ant d'individus de tout âge, de tout sexe, la plupart voués à l'oisiveté, ne peuvent que se dépraver mutuellement, ainsi amoncelés (permettez-moi cette expression) dans une étroite enceinte. Aussi, depuis plusieurs années, s'est il élevé des plaintes graves touchant la vie licencieuse qu'on mène dans cette maison. Les désordres se sont nécessairement accrus dans ces derniers temps, par l'ésprit d'indépendance, de division et d'anarchie qui s'y est introduit', Riffard and Martin, op. cit. (note 45), 22-3.
} 


\section{Ingrid Sykes}

the findings of the Committee of Public Assistance. The reasons given for closing the institution were not plausible, it explained. ${ }^{48}$ The Hospice had special qualities that should be preserved: 'Humanity, justice and the general interest call for the preservation of this precious hospital. ${ }^{49}$ The system of Jurors, previously attacked for its insularity, was suddenly praised for its qualities of corporative self-regulation: 'They support each other and watch over each other; if there is a disturbance they are alerted immediately as it is in everyone's interest to bring it to an end.... ${ }^{50}$ In response to the criticism that the institution was only for the privileged few, observers replied that, as well as accepting blind people from Departments beyond the Paris zone, the institution could act as a model for the establishment of other similar institutions throughout the country, as it had originally in the Middle Ages. The report decried Cardinal de Rohan and his tyrannical administration of the institution. It praised those administrators who had supported members of the community. One, a M. Maynier, for example, had 'raised his voice for the protection of the unfortunate and oppressed Blind. ${ }^{51}$ The notion of voice here implies sympathy and compassion. Citizens should join their voices with those of Quinze-Vingts described later in the document as 'les voix des malheureux' ['the voices of the unfortunate']. Such political authorities recognised the blind voice in much the same manner as mediaeval listeners did. They acknowledged that the blind voice expressed at Quinze-Vingts played an important role in society and should be cared for.

\section{Human Rights: Resisting Voices}

Quinze-Vingts members, in turn, situated themselves within this Revolutionary call for human rights. In demanding their right to a voice, they referred not only to their original charter of spiritual blind privilege; they also referred to Revolutionary observations, enshrined in the Declaration of the Rights of Man [Déclaration des Droits de l'Homme], acknowledging all men (including 'les malheureux') the right to a voice. Quinze-Vingts members sounded the rights of all citizen-patients to make demands. They echoed the parliamentary observation that some citizens required humanitarian assistance and a sympathetic ear from those in political control. To raise one's voice was to stage a political act of empowerment, as conveyed in the meaning of 'la voix' as a term of personal enfranchisement ('donner la voix' means 'to vote'.) Such defiant voices, however, commenced as soon as Quinze-Vingts was placed under enquiry in 1789. The blind asserted their voices as soon as they began to be perceived as a threat.

In 1790, the Quinze-Vingts blind wrote a long letter to the National Assembly complaining about their treatment. ${ }^{52}$ It was lodged by a lawyer and signed by twelve

\footnotetext{
${ }^{48}$ Observations pour les aveugles de l'hôpital des Quinze-Vingts, Sur le projet de décret du comité de secours de la convention nationale, pour la suppression de cet hospital (Paris, 179-, 21, Collection, Archives de la Revolution française.

49 '[L]'humanité, la justice et l'intérêt general sollicitent la conservation de ce précieux hospice', ibid., 9.

50 'Ils se soutiennent et se surveillent les uns les autres; s'il y a quelque déréglement, ils en sont aussi-
}

tôt avertis, et ils ont égal intérêt à le faire cesser...,' ibid., 21.

51 '[F]aisait entendre sa voix pour la défense des malheureux Aveugles opprimés', ibid., 32-3.

52 'Requête à l'Assemblée nationale, sur l'administration de monsieur le cardinal de Rohan, de l'Hôpital royal des Quinze-Vingts, par tous les frères aveugles des Quinze-Vingts', repr. (Paris: De l'impr. de P.-Fr. Didot le jeune, 1790), Collection, Les archives de la Révolution française. 


\section{Sounding the 'Citizen-Patient'}

members of the Jurors: François Monier, François Gonoro, Jean Prevôt, Louis Godevier, François Hoyez, Pierre de Longue, Nicolas Chadrin, François Crevier, Jean Louis Barre, Pierre le Bros, Jean Louis Baudoin, and Caizergue. For ten years, they wrote that the 'virtuous' members had been subject to the most 'deplorable' abuse by corrupt outsiders, such as the Cardinal de Rohan. 'This class of men whose fate and misfortune are so moving for thinking souls, could hope that it would always be comforted in its adversity." 53 They requested that their original form of administration be restored and attacks on their members be immediately stopped. They asked that their special status, conferred on them by the Declaration of a King [Déclaration du Roi], should be given the direct protection of the National Assembly. The 'Blind Brothers' ['Frères Aveugles'] wrote a second petition to the National Assembly in 1792, demanding to be placed under the administration of the Departments as a whole, not under the scrutiny of the local municipality, emphasising that their institution was established for 'all the blind of the Empire'. ${ }^{54}$ As if to demonstrate their desired independence, they had their demands transcribed by a sighted member of their community, instead of printed, and deposited the document themselves rather than through a lawyer. They signed their declaration not with a list of names but with the imperative phrase 'Et Ferez Justice'.

During the immediate post-Revolutionary period, Quinze-Vingts members played crucial roles in maintaining their independence. In 1802, they wrote to protest against the amalgamation with the Institute for Blind Youth. They complained that the plan would mean a reduction in their pension, and 'Perpetual Celibacy', since they would have to abandon their wives and children for a life of repression. ${ }^{55}$ 'It offends your Sensitivity, Citoyen Consul, that the Blind are treated as old people who will end their days in the hospice, or like sick persons who are there for a short time to recover their health, and, which is even harder, like vagrants to be removed from society,' insisting instead that 'the blind are fathers with families or may become so; they are welcomed at any age at the Quinze-Vingts and enjoy all the freedoms of the other Citizens. ${ }^{56}$ In this statement, members demanded, not only their right to unqualified support as 'unfortunates' of the State, but the freedom to express themselves as members of a newly established democratic society. Members also requested that they be put under the jurisdiction of the 'National Assembly' explaining that it was 'the only authority in which these unfortunates can place their confidence and their hope. ${ }^{57}$ Ironically, they also signed off the petition with a reference to their original foundation of royal privilege: 'You will not suffer, Citoyen Consul, that the history book, already open to record your virtues and your

\footnotetext{
53 'Cette classe d'hommes dont le sort et le malheur sont si attendrissants pour les âmes pensantes, pouvait concevoir l'espérance d'être toujours soulagée dans son infortune': ibid., 8 .

54 'Pétition presentée á l'Assemblée Nationale par les frères aveugles et voyants de l'hôpital des QuinzeVingts', 19 September 1792. All manuscript petitions from this point on are from B 107-6678 B 1096724 , B 1156829 AQV.

55 'Pétition présentée au premier Consul par les Aveugles de l'hospice des Quinze-Vingts', manuscript, [n.d.]
}

\footnotetext{
56 'Il répugne à votre Sensibilité, Citoyen Consul, que les Aveugles soient traités comme des vieillards qui vont terminer leurs jours dans l'hospice, ou comme des malades qui y sont momentanément pour y recouvrer la Santé, et, ce qui est encore plus dur, comme des vagabonds dont on doit purger la société,' insisting instead that 'les aveugles sont pères de familles ou peuvent le devenir, ou les reçoit á tout âge aux Quinze-Vingts; ils y jouissent de toutes les libertés des autres Citoyens': ibid.

57 '[L]a seule autorité en qui ce malheureux puisse metter leur confiance en leur ésperance': ibid., n.p.
} 


\section{Ingrid Sykes}

good deeds - contains these words - "In the year IX of the Republic, the Hospice des Quinze-Vingts founded by a King, protected by all, enriched by good house-keeping and by its legacy", 58 In their demands, the post-Revolutionary blind referred to all past political regimes, however diverse, who had supported their right to a voice.

\section{Silencing the Quinze-Vingts Voice}

The Quinze-Vingts voice was perceived once again by state authorities as threatening immediately after it was celebrated as exemplary. After the restoration of the institution in 1793, the authorities aimed to shut down the literal musical voice of the institution and its associated figurative voice. The independent ethos of the institution continued to be perceived as a persistent source of the problem. Quinze-Vingts members were forced to put up with administrators appointed externally. ${ }^{59}$ The authorities also implemented hygienic reform to drown out the institution's spirited vocalising of blind affliction. A healthy voice would reform a diseased one, the authorities believed. Quinze-Vingts street music and begging would be controlled or eradicated through regulation. Musicians would be educated with an appropriate voice within the institution. This would not only improve the literal voices of the blind, but also reform the problematic figurative voice of the institution. Violent voices would be transformed into beautiful ones which would make the public healthy when they heard them.

After the institution's re-establishment, any constructive dialogue between the institution and political authorities collapsed. Political documents either do not acknowledge the Quinze-Vingts 'voice' (the politicians are simply not listening) or attend to it by attempting to silence it. Quinze-Vingts members protested against this treatment and continued to vocalise their presence in the urban environment through music. The tense situation was summed up by the Agent General [Agent Général] when he reported to the Minister of the Interior in 1801: 'The blind should be visited and be involved with so that you can get to know them better; they are capable of anything; they are allowed to do all things and they think that their infirmity protects them from everything. ${ }^{60}$ The blind are defined as threatening through their ability to express an unlawful voice. Only by experiencing this voice first hand, the Agent General warned, will the authorities know just how dangerous it could be. The authorities saw the merger between Quinze-Vingts and the Institute for Blind Youth as an ideal opportunity to reform the voice of the entire institution. It would no longer be a place of bodily deviance, they argued, but of utility and cure.

To articulate the blind voice was considered a mode of antisocial behaviour. Begging was outlawed in the immediate post-Revolutionary period for the reason that the institution was hiding money unlawfully. Yet laws against begging remained enforced on the

\footnotetext{
58 'Vous ne souffrirez pas, Citoyen Consul, que le livre de l'histoire, déjà ouvert pour y enregistrer vos vertus et vos bienfaits - porte ces mots - "En l'an IX de la République, l'Hospice des Quinze-Vingts fondé par un Roi, protégé par tous, enrichi de la propre économie et de ses héritages".' Ibid. , n.p.

${ }^{59}$ Weygand, op. cit. (note 3), 168.
}

\footnotetext{
60 'Il faut fréquenter les aveugles et avoir à faire avec eux pour les connaître, ils sont capables de tout; ils sont autorisés á tout et ils pensent que leur infirmité les met à l'abri de tout', Agent Général, Draft of letter to the Ministre de l'Intérieur, manuscript, 22 floréal, an 8, B106 6609-6613 Règlements AQV.
} 


\section{Sounding the 'Citizen-Patient'}

basis that they were associated with violence. In 1795, the Minister of the Interior wrote to the Director that a group of blind from the institution had been seen 'in the countryside to beg alongside ill-intentioned people and this is disturbing the public peace'. ${ }^{61}$ The blind were not to wander from the house on their own without permission, he explained, and must be subject to 'the repressive laws on begging' to prevent such a situation occurring again. Musical instrument playing was officially permitted but a blind musician could easily be accused of begging rather than performing and then prohibited. Laws against begging were incorporated into the rules and regulations of the institution during the Consulat and the Empire. The implementation of a set of policing regulations in 1800 by the then Minister of the Interior, Lucien Bonaparte, combined both a ban on begging and the official appointment of a Director or Agent General, not only to oversee the finances but also to supervise the movements of members. The blind-afflicted body now required containment both inside and outside the institution. Like members of the post-Revolutionary National Assembly, Bonaparte considered the institution like a body out of balance. It needed a healthy regime to change its behaviour. It was in a state of 'the greatest disorder' which would be completely transformed through the creation of 'a good system of administration' and the establishment of 'a gentle and humane regime but fairly strong in order to maintain order, subordination and manners'. ${ }^{62}$ The regulations centred on issues of hygiene and mess. If members threw rubbish into the corridors or left excrement on the toilet floor they would be fined; if they kept pigeons or rabbits, the animal would be confiscated and the inhabitant fined; dog mess would incur a fine. They were forbidden to write on the walls, stairs or other buildings. Other rules addressed the supposedly unruly behaviour of the children of members, who traditionally lived in the compound with their parents. If they were not taken to school, or played violently, threw stones or fireworks, the parent would lose their journal subscription. Members were also forbidden to have visitors to stay overnight or for a meal without permission. A health officer would inspect the premises regularly. Such regulations were attempts to impose practices of health on an institution that was essentially considered unwell.

In 1801, the then Minister of the Interior, Chaptal, attempted to integrate Haüy's institution entitled, the National Institute for Blind Workers [Institut National des AveuglesTravailleurs] - originally the Institution of Blind Youth [Institut des Jeunes Aveugles] with Quinze-Vingts. Weygand has drawn attention to the essentially productivist agenda of Chaptal's decision. Chaptal saw the institution as a workhouse. ${ }^{63}$ This was totally contrary to Haüy's vision of the intellectual blind self, who read, wrote and learned music. Weygand describes in detail the disciplined nature of the new regime. It was undeniably physical. 'More than half of the blind youth's day was thus spent in the wool spinnery,

\footnotetext{
61 '[D]ans les campagnes pour y mendier et se font accompagner par des gens mal intentionnés ce qui alarme la tranquillité publique': La Chef de la Deuxième Division des Bureux du Ministre de l'Intérieur, Letter to the Administration of QuinzeVingts, le 30 prairial an 4, manuscript.

62 ' [U]n régime doux et humain mais assez fort cependant pour y entretenir l'ordre, la subordination, et les mœurs': Lucien Bonaparte, Ministre de
}

l'Intérieur, Letter to the Agent Général de QuinzeVingts, le 17 floreal an 8, Paris, manuscript. For the regulations see 'Etablissement National des QuinzeVingts: Règlement de Police de l'Intérieur de l'établissement', 13 June 1800, F15 2581. Archives Nationales, Hospice et Secours Quinze-Vingts: Règlement intérieur an VIII and the file, B106 66096613 Règlements AQV.

${ }^{63}$ Weygand, op. cit. (note 3), 158-64, 234-52. 


\section{Ingrid Sykes}

with the exception of a few students admitted to the music class or the print works, ${ }^{64}$ Haüy was unhappy with the emphasis on manual labour. He resigned because of conflict with Chaptal over the subject. It is possible to argue, however, that Haüy's agenda was not so far from Chaptal's as might at first be thought. Both were attempting to shut down the blind voice through programmes of reform. Haüy was, of course, attempting reform in a much more sensitive and progressive way. He took account of the intellectual abilities of the blind rather than relegating them to the workhouse. 'Our institution will offer help to all, either for study, or for the practice of their Art', ${ }^{65}$ he explained in his 1784 manifesto. Haüy developed a system of imprinting musical characters, along with letters of the alphabet, so that the blind could read and memorise music held in the 'Bibliothèque de goût' ${ }^{66}$ Haüy admired the learning of the 'old Masters' such as Bach, as well as French composers, Couperin and Balbastre. ${ }^{67}$

Haüy's programme of reform belonged to a much broader culture of musical education designed to cultivate the blind person. The musical education of the young blind during the post-Revolutionary period was profoundly influenced by the composer and music theorist Jean-Philippe Rameau. Rameau reduced some of the more complex acoustical theories of Cartesian mathematics into a single palatable system for pedagogical use. ${ }^{68}$ The simplicity and geometry of Rameau's system made it perfect for teaching, and it formed the basis of harmony and composition programmes of post-Revolutionary institutions, the Paris Conservatoire and the young blind at the Institute for Blind Youth and Quinze-Vingts. ${ }^{69}$ Students could memorise the progressions, absorb them and practise them over a year or more when they entered the institution. Only after this process of intensive learning and practice could they produce performances on their instrument of choice and compositions of real 'taste'. After memorisation, progressions could be skilfully reversed to create a perfect arch form, and in turn, the invention of a complete piece of music. Rameau's system catered especially for blind pupils, a point he makes plain in the full title of his 1761 teaching manual, Code de musique pratique, ou méthodes pour apprendre la Musique, même à des aveugles... [Practical Music Code, or Methods for Teaching Music, even to the Blind...]. Blind students could shape their fingers and tune their ears producing the best results, precisely because they could not see. The system can best be described as a kind of physical intuition based on strict harmonic practice. As Rameau explained:

Using this system, the fingers acquire a knowledge which... nourishes the ear of all the harmonic routes, while it presents the mind with a reliable example of all the rules in which it must be

\footnotetext{
${ }^{64}$ Weygand, op. cit. (note 3), 238.

65 'Notre institution va leur offrir á tous des secours, soit pour l'étude, soit pour la pratique de leur Art': Haüy, op. cit. (note 34), 85-6.

${ }^{66}$ Ibid., 86.

${ }^{67}$ Ibid., 89

${ }^{68}$ Jean-Philippe Rameau's pedagogical work, Code de musique pratique, ou méthodes pour apprendre la Musique, même à des aveugles [...] (Paris: Imprimerie Royale, 1761), was the
}

\footnotetext{
culmination of over fifty years of work on the science of music including his famous, Traité de l'harmonie (Paris: Ballard, 1722).

${ }^{69}$ Robert W. Wason, 'Musica practica: Music Theory as Pedagogy', in Thomas Christensen (ed.), The Cambridge History of Western Music Theory (Cambridge: Cambridge University Press, 2002), 46-77. Like the Conservatoire, the Institut adapted Rameau's teaching principles to their music programme.
} 


\section{Sounding the 'Citizen-Patient'}

educated, with the result that judgment, the ear and the fingers of intelligence work together to quickly produce the perfection that is desirable in this genre.... ${ }^{70}$

Crucially, it provided a 'cure' for the broken bodily music of street musicians. Street criers and popular instrumentalists left listeners cold, Rameau explained, because their music was based on an overly primitive theory of harmonics. ${ }^{71}$ Street melodies were unsupported by an appropriate harmonic system.

To educate musicians using such a system was to remedy the problem of the raucous blind voice. It would create a blind self who was harmonised through a systemised set of sonic and gestural signs. Haüy believed that young blind musicians, trained in his institution, would lead the way. But he would also have hoped that the musical programme would have influenced all at Quinze-Vingts after the amalgamation. He wanted to create a completely new voice for the institution that was in keeping with civilised musical programmes of the late eighteenth-century bourgeoisie. There is no doubt that Haüy's programme was invaluable to the young blind. But it could not be easily implemented alongside the blind voice at Quinze-Vingts. In 1816, the Blind Youth Institute departed Quinze-Vingts to form a separate institution once again. Haüy's musical programme was developed by the new director of the Institute for Blind Youth - now the Royal Institute for Blind Youth [Institution Royale des Jeunes Aveugles] - and continued to influence generations of young blind musicians. ${ }^{72}$ Quinze-Vingts musicians, however, continued to perform on the streets of Paris. They retained the right to voice the independence of their blind community. Yet they were met with further voices of political opposition that were to increase in volume as the century progressed.

During the Restoration, the Quinze-Vingts blind continued to petition for administrative independence. In 1824, they wrote to the Grand Almoner [Grand Aumônier], Gustave-Maximilien-Juste, Prince de Croÿ, their current Superior General [Supérieur Général], for an official restitution of the Jurors. ${ }^{73}$ The Jurors had continued to meet throughout the Empire and Restoration, though externally appointed administrators had

\footnotetext{
70 'Par cette méchanique, bientôt les doigts prennent. . . connaissance. . . nourrit l'oreille de toutes les routes harmoniques, pendant qu'elle présente á l'ésprit un exemple fidèle de toutes les règles dont il doit être instruit; de sorte que le jugement; l'oreille et les doigts d'intelligence concourent ensemble á procurer en peu de temps les perfections qu'on peut desirer en ce genre...': Rameau, Code, op. cit. (note 68), xiii.

71 "La phrase du Ton régnant doit être généralement la plus longue, et peut reparaître de temps en temps après celles de l'un de ses relatifs, mais non pas deux fois après le même, á moins que les phrases de l'un et de l'autre ne soient trés-brèves dans l'une des deux fois, sinon la monotonie s'y fait toujours sentir: tel est le défaut des Airs de Trompette, de Cor, de Musette et de Vielle. . Ecoutez les gens qui chantent et ce qu'ils crient dans les rues, rien ne vous prouvera mieux les purs effets de la Nature en pareil cas. . .De-lá vient qu'une Musique continuellement composée dans un Ton qui n'est
}

varié que par celui de sa quinte, comme sont les Airs de Trompettes, Cor, Musette, et Vielle, ne produisent aucun effet sur l'âme, si ce n'est par la variété des mouvens. .." Ibid., 139, 167.

${ }^{72}$ Sébastien Guillié, 'De la Musique', in Essai sur l' instruction des aveugles, 3rd ed. (Paris: Imprimé par les aveugles, 1820), 211-15.

73 'Mémoire des Membres des Quinze-Vingts addressé á Messieurs les Administrateurs Gouverneurs touchant la demande faite à Monseigneur le Grande Aumônier, pour obtenir le Rétablissement des Frères Jurés et la suppression des fournitures et retenues', Petition, manuscript, [n.d.] 1824; 'A Son Altesse Monseigneur le Prince de Croÿ Grand Aûmonier, Pair de France, Archevêque de Rouen, supérieur général de l'hôpital Royal des Quinze-Vingts', Petition, manuscript, 9 July 1824; 'A son Altesse le Prince de Croÿ Pair et Grand Aûmonier de France, Archevêque de Rouen, supérieur immediat de l'hôpital Royal des Quinze-Vingts', Petition, manuscript, 20 December 1824. 


\section{Ingrid Sykes}

often intervened in the running of the institution. Unhappy with the administrators appointed by the Prince, they demanded the official restitution of the Juror system in order to safeguard against what they perceived as unlawful external interference. Recent administrative intervention, they complained, had deprived them of precious income. Welfare - and in particular, bread - allowances had been mismanaged. Funds, generated by the members themselves, had been absorbed by unnecessary bureaucracy. It would be much more economically expedient, the blind explained, to hand all moneys directly to the newly restored Jurors, 'the observing and protective voice', ${ }^{74}$ who would then distribute the moneys appropriately.

From the 1830s, Quinze-Vingts musicians were increasingly subject to laws directly restricting their musical voices. Kudlick and Weygand have noted that during the Restoration, the Catholic ultra-royalists who ran the Quinze-Vingts looked 'particularly unfavourably upon their student musicians or singers who performed in such immoral places [as the café of the blind] at all hours'. ${ }^{75}$ In the 1820 s, the Almoner prohibited them from going to the café, a venue they had continued to use for musical performance after the Revolution. ${ }^{76}$ By the 1830 s, the authorities realised that if the blind insisted on performing at the café, boundaries had to be established by those in political control. In 1831 , they reluctantly granted permission for a band to visit the café on the condition that it conformed to a strict curfew. 'Most of the blind being able to devote themselves only to the art of music, the Administrator will decide the extent to which they must be permitted to carry out this activity, ${ }^{77}$ they declared. The restriction of blind voices during the 1820 s and 30 s coincides with an intense period of panic amongst the Parisian bourgeoisie concerning disease such as cholera. Kudlick has explained that this heightened anxiety came from a new shift in perception that:

Paris suffered from a kind of internal imbalance rather than from externally imposed conditions of geography and climate; the city was plagued by forces of its own making. Implicit in this view was a moral judgement: not only was the capital becoming sick, but the sickness was part of the very fabric of urban existence and resulted from human activity rather than mysterious natural forces. ${ }^{78}$

By focusing on the individual behaviour of the 'poor' and the environment that surrounded them, the bourgeoisie were reassured that they might not catch the disease. Quinze-Vingts had already been condemned as unhygienic. Now, all the sites outside the institution frequented by the Quinze-Vingts musicians were under threat.

\footnotetext{
74 '[L]a voix observative et defensive': 'A Son Altesse Monseigneur le Prince de Crö̈', ibid.

${ }^{75}$ Thérèse-Adèle Husson, Reflections: The Life and Writings of a Young Blind Woman in PostRevolutionary France, trans. and with commentary by Catherine J. Kudlick and Zina Weygand (New York: New York University Press, 2001), 117. Weygand has also drawn attention to a revival of the liturgical tradition at Quinze-Vingts during this period led by Jean-François Galliod: Weygand, op. cit. (note 3), $194-5$

${ }^{76}$ Abbé Sentier, Vicaire Général de la Grande Aumônerie de France, Chanoine de Chapître Royal de
}

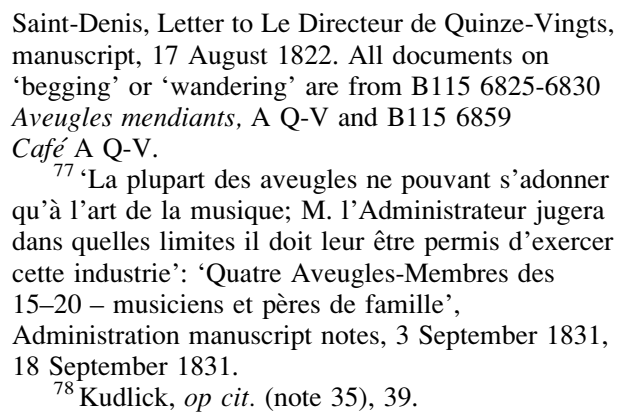




\section{Sounding the 'Citizen-Patient'}

Though musicians continued to perform on the streets, their movements were heavily scrutinised. The authorities forced members, in particular the musicians, to wear a military-style uniform when out and about. ${ }^{79}$ Such a uniform performed a completely different function from the fleur-de-lis robe offered to members by Louis IX at the institution's foundation. The original robe celebrated the blind voice with a dash of royal colour. Post-revolutionary uniforms were designed to muffle or mute it with an instrument of authority. This was followed by much tighter forms of restrictions on public movements enforced by the Préfecture de Police. ${ }^{80}$ In 1842, a list of Quinze-Vingts 'beggars' was drawn up under the title: 'The Blind who engage in any activity on the public highway in Paris either by playing various instruments, or singing, fortune-telling, or peddling objects with no value as a way of disguising their begging, ${ }^{81}$ Alongside a list of the licenced 'beggars' were their allocated positions on the streets of Paris and their chosen activity. Of the twenty-three individuals, eleven were instrumental musicians (seven clarinettists and four violinists), with the remaining (including an additional set of two small groups) selling matches or asking for alms near churches. Alongside the implementation of this system was a set of laws designed to ban the movements of Quinze-Vingts musicians outright. ${ }^{82}$ Travelling beyond Paris was now out of the question following the implementation of a revised and convoluted new application procedure. Inhabitants found 'begging' on the streets of Paris (either individually or in groups, though the latter was a more serious offence) could also be permanently thrown out of the Hospice, or have their pension dramatically reduced if they did not have the appropriate permission.

Attempts to silence the blind voice became much worse during the period of the July Revolution. The classification of Quinze-Vingts members as violent, poor and diseased was suddenly extended to include revolutionary. ${ }^{83}$ In 1847, a group of Hospice inhabitants was expelled from the institution, presumably for begging on the street. ${ }^{84}$ They found their way to the house of Victor Hugo who arranged alternative accommodation for them in a provincial parish. He complained vehemently to the Quinze-Vingts chaplain, Jean Prompsault, who had managed to save the Quinze-Vingts chapel from closure by the church authorities during the 1830s. Prompsault responded: 'The blind for whom you are concerned have been treated with a severity which, in my opinion, would be difficult to justify. I can state without fear of contradiction, that they are the best educated and the most peaceful men in the establishment' ${ }^{85}$ Prompsault and Hugo were amongst

\footnotetext{
79 'A Messieurs les Administrateurs de la Maison Royale des 15-20', Petition, manuscript, 26 March 1834, and Directeur de Quinze-Vingts, Letter to the Ministre de l'Intérieur (184- ), manuscript.

${ }^{80}$ Préfecture de Police, Letter to Le Directeur de Quinze-Vingts, 26 July 1838, manuscript.

${ }^{81}$ Ministre de l'Intérieur, Letter to Le Directeur de Quinze-Vingts, 1 August 1842, with attached 'Liste des "Aveugles qui exerçant dans Paris sur la voie publique une industrie quelconque soit en jouant de divers instruments, soit en chantant, disant la bonne aventure, ou colportant des objets de nulle valeur dans le but de masquer la mendicité à laquelle ils se livrent",.
}

\footnotetext{
${ }^{82}$ See Jean Prompsault, Les Quinze-Vingts (Carpentras: E. de Rolland, 1863).

${ }^{83}$ For key information on the intersection between disease and social unrest during this period see Kudlick, op cit. (note 35), 176-211.

${ }^{84}$ The expulsion is mentioned in the following documents: Ministre de l'Intérieur, Letter to M. Charussion, manuscript, 2 September 2008 and Abbé Prompsault, Letter to Victor Hugo, 27 August 1848, B 1036585 AQV, Lettre á Victor Hugo.

85 'Les aveugles auxquels vous voulez bien vous intéresser ont été traités avec une sévérité qu'il serait difficile à mon avis, de justifier. Ils sont je puis le déclarer sans craindre de recevoir un démenti, les
} 


\section{Ingrid Sykes}

the few public figures during the mid-century period to recognise the blind voice. But they were unable to prevent its silencing by the government. As Prompsault explained:

I have just received a letter from him [the Minister of the Interior] which states that this measure was intended to restore order, discipline and subordination, that it was successful in its aim, that the government of the Republic does not need to be persuaded to take an interest in the blind, and that $\underline{\text { I must not intervene in an act of internal administration. }}{ }^{86}$

Meanwhile, the Director proposed an ambitious and expensive renovation plan for the Quinze-Vingts site. ${ }^{87}$ Though the plan was never executed, major work began on the Bastille railway station next to the site in 1856. A brand new ocular clinic was built in 1870 , and the site quickly transformed into an institution primarily designed for surgical practice. ${ }^{88}$ The blind were temporarily removed from the site altogether in 1885 .

The mid-nineteenth-century period of Quinze-Vingts history was dominated by aggressive modification of the institution's architecture, resulting in complete transformation. The independence of the figurative blind voice was silenced through the remodelling of its mouthpiece (the institution) by authorities and knowledgeable experts into something quite new and different. Surgeons were eager to apply new methods in ocular surgery during this period to Quinze-Vingts patients and others throughout the world. They wanted to create a leading centre of ophthalmology in the capital. Yet their laudable aims also coincided with an assault on the blind voice. Just prior to the installation of the surgical clinic at QuinzeVingts, the Quinze-Vingts blind were the subject of a vicious verbal attack by Léonce Guyot-Montpayroux, an active enemy of the Empire and soon-to-be member of Gambetta's government of the Third Republic. Without mentioning them by name, he decried a group of citizens, 'Les Peureux et les Aveugles' ['The Fearful and the Blind'] dominating the tenth arrondissement of Paris. ${ }^{89}$ These citizens, he explained, were extremists, either reactionaries or revolutionaries, who refused to change or be cured through their weakness or stubbornness of character. They could be identified through the terrible sounds they created as they wandered around the countryside in groups of musical bands. 'Get close and listen to them while observing how each person likes to attract particular attention: the trombone will raise the pitch, the unfortunate clarinet will do its best not to be drowned out by the

hommes les mieux formés et les plus paisibles de l'établissement': Prompsault, ibid.

86 'Je reçois à l'instant une lettre de lui [Ministre de l'Intérieur] qui dit que cette mesure a eu pour but de ramener l'ordre, la discipline et la subordination, qu'elle a produit son effet, que le gouvernement de la République n'a pas besoin d'être stimulé pour porter de l'intérêt aux aveugles et que je ne dois pas intervenir dans un fait d'administration intérieure': ibid.

87 'Note historique sur l'origine des Quinze-

Vingts et renseignements sur les modifications apportés aux statuts de cet hospice', September 1846 and other documents in file, D 25388 AQV, Plan de travaux de l'isolement. See also Guillaumat, op. cit. (note 12), 107.

${ }^{88}$ Eye surgery had been practised at QuinzeVingts since the late eighteenth century. Zina
Weygand, Les causes de la cécité et les soins oculaires en France au début du XIXe siècle (1800-1815) (Vanves: Centre Technique National d'Etudes et de Recherches sur les Handicaps et les Inadaptions, 1989), and also Helen Corlett, "“No small uncertainty": Eye Treatments in EighteenthCentury England and France', Medical History, 42 (1998), 217-34. However, it was subordinate to the use of the site as accommodation for the blind and partially sighted until the opening of the clinic in 1870, see Guillaumat, op. cit. (note 12), 112-22, and also Doctor Fieuzal, Clinique Ophthalmologique de l'Hospice des Quinze-Vingts (Paris: Agnes Delahaye, 1876).

${ }^{89}$ Léonce Guyot-Montpayroux, Peureux et aveugles: Notice médico-politique sur l'arrondissement de l'X (Paris: Dentu, 1864). 


\section{Sounding the 'Citizen-Patient'}

noise, and in a short time it will be a cacophony which will make you wish you were deaf. ${ }^{, 90}$ Behind the attack was a political message -'In France, the Interior Administration is thus; when it thinks that an eye is being kept on it, it acts in the same way as the clarinet that I have spoken about ${ }^{91}$ - but the characterisation of the blind voice as threatening was all too familiar. The blind voice was a serious social problem and should be silenced.

Aside from efforts to maintain the voice of the institution, the blind actively protested against legislation designed to curb their voices. They continued to move around outside the institution flaunting their blind voices during curfews. They discarded the uniform designed to muffle their voices on the street, complaining so vehemently about the restriction that the Director recommended the rule be dropped. ${ }^{92}$ When work began on the Bastille railway station they complained that the noise from the outside streets was unbearable. ${ }^{93}$ Their voices, by implication, would be drowned out. A group of musicians from the institution was granted permission to perform on the streets of Paris at the same time. ${ }^{94}$ Unwanted noise would, once again, be met with blind voices. Amongst these was François Leclerc, who requested permission to perform his clarinet 'on the bridges of the capital'. ${ }^{95}$ By articulating their voices, Quinze-Vingts members presented the authorities with a formidable challenge. Their vocalic mode of utterance gave them a particularly powerful presence in the urban landscape. They presented themselves in the highly public domain of the urban Parisian street promoting a bodily image and vocal language that resisted any form of intervention by experts. The authorities found such vocalising bodies difficult to suppress. Lithographs printed during the period demonstrate that Quinze-Vingts musicians continued to be a lively presence in the urban environment despite regulations designed to suppress their activities at the time (see Figure 2). ${ }^{96}$

Quinze-Vingts members managed to maintain the right to sound the blind voice in the postRevolutionary period, but they were met with a series of authoritarian voices designed to silence them. Such responses were in keeping with anxieties over public health demonstrated amongst the bourgeoisie. The most sympathetic of these was produced by Valentin Haüy, who desired reform amongst the blind through attention to social and intellectual improvement. Political authorities were much harsher in their orders. They used legislation to silence the blind voice. Yet their efforts were met with voices of resistance. Quinze-Vingts members protested against laws designed to silence them by continuing to sound their voices. They ignored curfews and continued to insist that protection of the Quinze-Vingts voice should be upheld.

It is crucial that we acknowledge the blind voice of the post-Revolutionary period. Voice was important to the blind's sense of self-determination. Utterance gave blind

\footnotetext{
90 'Approchez-vous et écouter-les en les observant chacun d'entre eux voudra se faire particulièrement remarquer: le trombone haussera le ton, la malheureuse clarinette fera tous ses efforts pour ne pas se laisser écraser par le bruit, et au bout d'un instant ce sera une cacophonie qui vous fera regretter vivement de n'être point sourd': ibid., n.p.

91 'En France, l'administration inférieure est ainsi; lorsqu'il pense qu'on a l'œil sur elle, elle fait comme la clarinette dont je viens de parler': ibid., n.p.

92 'A Messieurs les Administrateurs de la Maison, Royale des 15-20', Petition, manuscript, 26 March 1834.
}

\footnotetext{
93 'A Messieurs les Administrateurs de l'Hospice Royale des 15-20', Petition, manuscript, n.d.

94 'Etat des musiciens aveugles autorisés à stationner sur les ponts de la capitale', manuscript, 26 Jan. B 1246953 AQV, Aveugles musiciens autorisés.

${ }^{95}$ Préfecture de Police, Letter to Le Directeur de Quinze-Vingts, 28 January 1853, B 1246964 AQV, Leclerc: Lettres; and Préfecture de Police, Letter to Le Directeur de Quinze-Vingts, 25 January, 1853 B 1246953 AQV, Aveugles musiciens autorisés.

${ }^{96}$ Gottfried Engelmann, 'Les Musiciens aveugles', lithograph, 1828, Wellcome Images.
} 


\section{Ingrid Sykes}

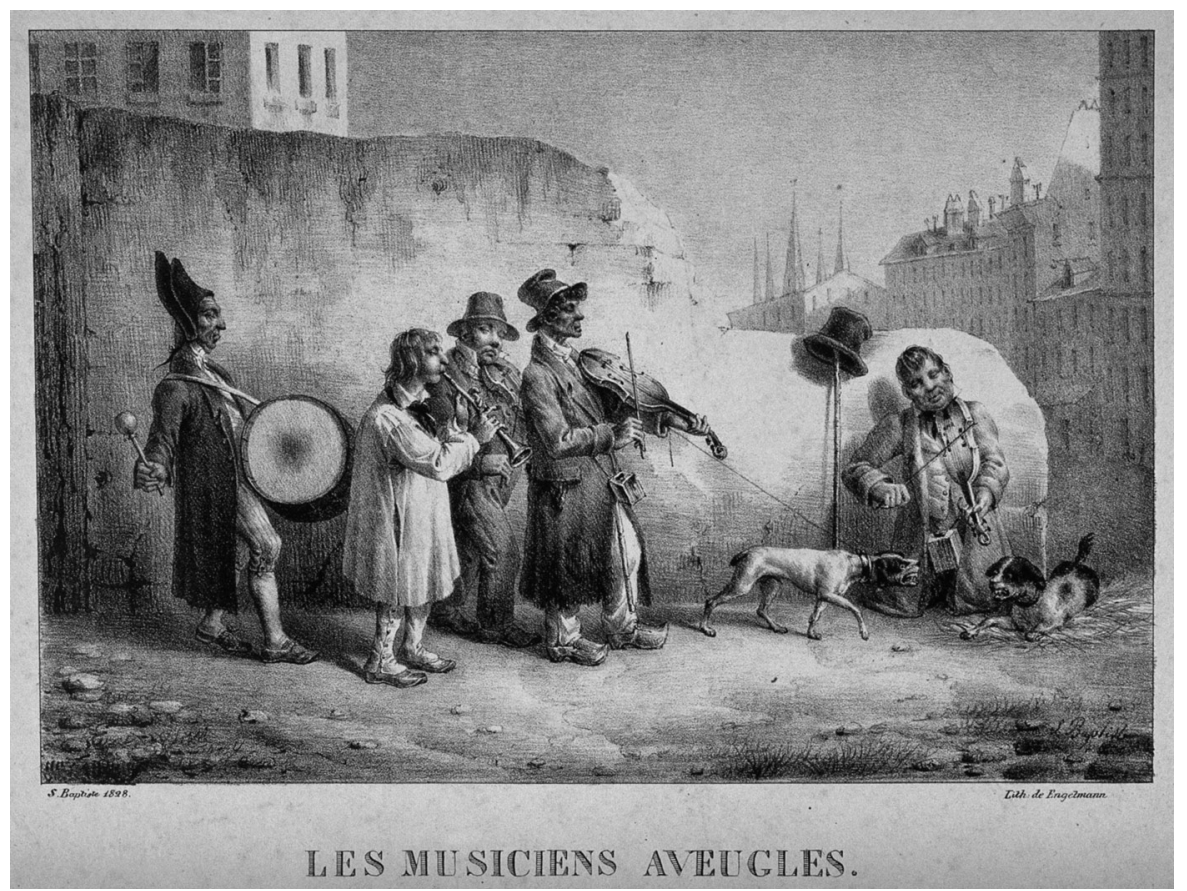

Figure 2: Gottfried Engelmann, 'Les Musiciens aveugles', lithograph, 1828. Courtesy: Wellcome Library, London.

musicians a sense of vocal power that was attached to a highly embedded, culturally defined status. They took care to continue to sound the blind self because it mattered to them. Such vocal contributions, however, were much more than simply random acts of self-interest on behalf of a small minority group. They helped shape the figure of the post-Revolutionary citizen-patient in a particular hour of need. By expressing their collective voices, the blind were in many ways asserting the voice of the liberated citizen-self that so many French thinkers and writers had dreamed of in the period prior to the Revolution. The blind were living proof that the citizen-patient had the right to speak up and engage in a dialogue with their political and medical carers. Citizen-patients were members of a broader community of citizen-selves. Political authorities also used voices to assert authority. Their unwillingness to listen to the blind voice indicates the level of political anxiety towards particular kinds of dialogue. The citizen-patient required the blind voice because its parameters of care were, in many ways, far too prescriptively confined. To acknowledge the sounding citizen-patient is to evaluate its identity more fully. The citizen-patient at the Hospice des Quinze-Vingts had a clear and startling voice.

\section{Acknowledgement}

This work was supported by the Wellcome Trust (075002). 